\title{
Овчинникова В.Е.
}

\section{Концепт «Родина» в творчестве двуязычного якутского поэта Алексея Михайлова: опыт сравнительно- сопоставительного анализа}

\author{
Ovchinnikova V.E. \\ Concept "Homeland" in the works of bilingual poet Yakutsk \\ Alexei Mikhailov: experience of comparative analysis
}

Данная статья посвящена изучению концепта «Родина» в контексте литературно-

художественных и философских исканий в творчестве якутского писателя Алексея

Михайлова. Произведения двуязычного поэта $A$. Михайлова сопоставлены со стихотворениями о Родине якутского поэта С. Данилова и русского поэта В. Федорова

Ключевые слова: концепт "Родина», русскоязычная литература Якутии, Якутия, А. Михайлов, С. Данилов, В. Федоров

\section{Овчинникова Вера Егоровна}

Студент

Северо-Восточный федеральный университет им. М.К. Аммосова

г. Якутск. ул. Белинского, 58
This article is devoted to the study of the concept of "homeland" in the context of literary and philosophical inquiry in the work of the Yakut writer Alexei Mikhailov. Works bilingual poet Alexander Mikhailov compared with poems about the motherland of the Yakut poet S. Daniel and Russian poet Vladimir Fedorov

Key words: concept of "homeland", Russianlanguage literature YakutiaYakutia, A. Mikhailov, S. Danilov, V. Fedorov

\section{Ovchinnikova Vera Egorovna}

Student

North-Eastern federal university named M.K.

Ammosov

Yakutsk, Belinsky st., 58

Научный руководитель: к.ф.н., доцент Дишкант Е.B.

В современной когнитивной лингвистике стержневым становится понятие «концепт». Его изучению посвящены труды многих отечественных и зарубежных ученых. Термин концепт введен в научный оборот С.А. Аскольдовым в статье «Концепт и слово», опубликованной в 1928 г. С точки зрения ученого, концепт есть мысленное образование, которое замещает нам в процессе мысли неопределенное множество предметов одного и того же рода. Каждый концепт, как сложный ментальный комплекс, включает в себя, помимо смыслового содержания, еще оценку и отношение человека к отражаемому объекту [1, с.24]. 
Мотив Родины - один из повторяющихся когнитивно-культурологических мотивов в поэзии Алексея Константиновича Михайлова, прослеживающийся в разных аспектах на всем протяжении творческой деятельности писателя.

Как истинный патриот своей родной земли, А. Михайлов включает в понятие Родина, прежде всего, Якутию. Через традиционные пейзажные зарисовки родного края проявляется национальный взгляд на мир. У любого якутского писателя природа занимает особое главенствующее место как в жизни в целом, так и в творчестве. Тема природы в поэзии А. Михайлова тесно связана с темой малой родины. В самих пейзажных зарисовках выразилось стремление писателя запечатлеть картину своей родной земли: «В небе спелая звезда / Земляникою мерцает. // К утру солнце обещает / В небе спелая звезда. // Приходите, я вас жду // Во дворе снега белеют, / И в печи дрова алеют. // Приходите, я вас жду» [7, c.19].

Якутов часто привлекают реалии леса, деревьев, кустарника, а не камня, как в поэзии народов Кавказа. У жителей тайги, у якутов - растения ассоциируются с изобилием и объединением. Например, в якутских песнях люди объединяются, «подобно высоко растущему лесу», становятся защитой «словно крупный лес». Национальное своеобразие особенно явственно ощущается в литературе, когда поэты прибегают к образам растений. Трепетное отношение к природе, тонкое чувство родной земли, любовь и нежность к ней проявляются во многих стихотворениях якутского поэта. Так, в стихотворении «Монолог сосны», сосна обладает способностью говорить и чувствовать: «Я к небу тянулась, я крону растила, / Ветрами качало, дождями мочило. // И снегом пуржистым меня засыпало, / И солнцем искристым меня ослепило...» [7, с.25].

В произведениях поэта отчетливо слышится чувство гордости за свою Якутию: «Понятия «Россия» и «Москва», / «Саха сирэ» перемешались круто. // В моей судьбе. Поет душа якута, / В ответ рождая братские слова» [6, с.15].

Река Лена занимает особое место в творчестве якутских писателей. Ее красоту воспевали многие писатели, в том числе основоположники якутской литературы, С. Омоллоон, А.Е. Кулаковский, П.А. Ойунский и другие. Так, и для А. Михайлова тема малой Родины, Якутии неизменно и неразрывно связана с рекой: «Вечность... // Родина... // Река... // Родина, река и вечность» [5, с.30].

Лена для поэта как незаменимый источник сил, место, куда всегда можно вернуться, открыть перед ней душу и не бояться быть отвергнутым: «Дружище, нам близко до дальней звезды. // У этой прозрачной и вольной воды / Нам выпало счастье родиться. // Так будем с тобой всегда молоды / Перед натиском счастья, напором беды, / А Лена всегда даст напиться!» [5, с.13].

Лена как мать, как Родина, как детство и юность. В стихотворении «У человека должна быть река...» А. Михайлов воспринимает реку как друга и спутника всей его жизни: «У человека должна быть река, / В которой мамы ласковая рука / Его купала, где сказал отец, / Увидев крепкий взмах: «Ты молодец!»... // У человека должна быть река, / Амур иль волга, Лена иль Ока, / Которую увидишь в час крутой / Пред роковой, итоговой чертой» [5, с.30]. 
В творчестве А. Михайлова концепт «Родина» выражает глубокую привязанность к родной земле и, прежде всего, к родине отца - Амге, где поэт провел свое детство. Истоки его жизни, а позже и творчества - здесь, где родились, жили и погибли его предки, где он проводил каждые свои школьные каникулы, где остались только самые приятные воспоминания из детства: «После будут годывехи, / Зимы, весны, горы, реки, / Но останется навеки, / Навсегда. // Это лето праздник света. // И закаты, и рассветы, / И амгинская заветная / Вода!» [6, c.12]

Воспевая красоту малой Родины, А. Михайлов не оставляет без внимания традиции и обычаи своего народа. Так, в стихотворении «В небе спелая звезда...» упоминается древнейшее эпическое искусство якутов, которое занимает центральное место в системе якутского фольклора: «Я спою вам олонхо. // О бессмертье в нем поется, / Там добро со злом дерется. // Я спою вам олонхо», что, безусловно, говорит о знании, уважении и почитании поэтом истории, традиций, фольклора и обычаев родного народа [7, с.43].

По близости духа, по любви к Родине, по стилю передачи этой любви и уважения А. Михайлова можно сравнить с другим, не менее выдающимся якутским поэтом, певцом малой Родины, Семеном Даниловым. Поэт так же, как и А. Михайлов, любит и хорошо знает родной фольклор, поэтому его поэзия очень близка народному творчеству и схожа по стилю, национальному взгляду на мир с творчеством А. Михайлова: «Допето олонхо, умолк олонхосут // И жизнь вокруг опять обычная, простая, / И нет богатырей, и кони их не ржут, / И стрелы не свистят, моря перелетая» [3, с.67].

Творчеству А. Михайлова присуща мягкость повествования, доверительная и свободная интонация, как и в стихотворениях С. Данилова: «Будто слышат волшебную фразу - / Оживляются лица людей, / Словно им посчастливилось сразу / Повстречаться с Якутией всей» [4, с.54].

Тема Родины у якутского поэта наиболее полно и ярко раскрывается через пейзажные зарисовки, которые отражают национальное мировидение и звучат как исходное традиционное возвышение природы с неизменным представлением единства человека с природой родного края, а также взаимной связи природы и поэзии. Например, зимний пейзаж заявлен концептом снег, как и у А. Михайлова, символизирующим чистоту стремлений человека. Снежные просторы тундры и зимняя тайга в размышлениях поэта олицетворяют бесконечность времени, таящего противоречия жизни и судьбы, преодоление которых необходимы для самоутверждения человека. Назовем такие стихотворения, как «Хаар» («Снег»), «Маннайгыхаар» («Первый снег»), «Хаар сибэккилэрэ» («Цветы из снега»), «Кыһынгытыа» («Зимний лес»), «Кыһынгыырыа» («Зимняя песня»). Это объясняется особенностью национальной культуры, ведь литература свои существующие изобразительные средства берет из самой жизни, окружающей среды. Родная среда, особенности климата, культура, быт неизгладимо запечатлелись в творчестве якутского поэта С. Данилова и двуязычного поэта А. Михайлова.

А. Михайлов и С. Данилов воспевают свой край, свою малую Родину влюбленно. Их стихи колоритны, рельефны и зримы. В их произведениях присутствуют не условные, а самобытные образы, отражающие национальное восприятие мира. 
Концепт «Родина» представлен и в творчестве Владимира Федорова, русского поэта, прозаика, драматурга. Творчество поэта пронизано русским национальным своеобразием, характеризующимся использованием фольклорных мотивов и образов, постоянных эпитетов и сравнений, слов с уменьшительно-ласкательными суффиксами: «Ни письма, ни весточки... // В походе / Затерялся где-то мил-дружок. // Десять лет она уже выходит / На высокий Ленский бережок» [9, с.19]. В отличие от С. Данилова и А. Михайлова, В. Федорова в большей степени повествует о большой Родине - России, Отчизне. Ее описание носит патриотический характер, часто встречается мысль о священном долге перед Родиной: «Русь в атаку шла, / Русь у нас была / Разной. // Только кровь у нас, как у них, цвела / Красным. // Русь навстречу шла, красный флаг несла, / Пела. // Только полегла, как и мы, в снегах / Белых»[9, с.38]; «За спиной лежит судьбаРоссия, / Впереди - чужая полоса... // Двадцать лет нас родина растила, / Мы вернем ей долг за полчаса» $[8$, c.14].

Таким образом, сопоставив стихотворения о Родине трех поэтов, мы пришли к следующему выводу: концепт «Родина» у С. Данилова и А. Михайлова в большинстве стихотворений представлен образом Якутии, как правило, через призму национальных фольклорных образов и народных представлений. В их произведениях неизгладимо и прочно запечатлены родная среда, климат, традиции и быт якутского народа. У русского поэта В. Федорова образ родины Руси является более масштабным. Умело сочетая живые, конкретные детали в поэзии, он поднимается до поэтических обобщений, и тогда образ родного края вырастает до всеобъемлющего понятия Родины, Отчизны: «Я родился в своей Вселенной, / В самом сердце земли Саха, / Где встречается с мудрой Леной / Кареглазая дочь Лунха...» [9, с.31].

\section{Список используемых источников:}

1. Аскольдов С.А. Концепт и слово // Русская словесность. М.: Academia, 1997. С. 21-41.

2. Данилов С.П. Звучание тайги // Советская Россия. М., 1972.

3. Данилов С.П. Избранное. Якутск: Кн. изд-во, 1977.

4. Данилов С. П. Избранное. Якутск: Кн. изд-во, 1984.

5. Михайлов А.К. Серебряная ночь: стихи, проза. Якутск: Бичик, 1995.

6. Михайлов А.К. Белое чудо: Стихи. Якутск: Кн. изд-во, 1990.

7. Михайлов А.К. От утренней звезды и до звезды вечерней: Стихи о любви. Якутск:

Сахаполиграфиздат, 1993.

8. Федоров В.Н. Звезда голуболикой Жаннет. Якутск: Бичик, 1993.

9. Федоров В.Н. Небесный пилигрим. Якутск: Бичик, 2006.

(C) 2016, Овчинникова B.E.

Концепт "Родина» в творчестве двуязычного якутского поэта Алексея Михайлова: опыт сравнительно-сопоставительного анализа (c) 2016, Ovchinnikova V.E.

Concept "Homeland" in the works of bilingual poet Yakutsk Alexei Mikhailov: experience of comparative analysis 